This is the author accepted manuscript to appear in the Journal of Language, Aggression and Conflict. As such, it is under copyright; the publisher should be contacted for permission to re-use or reprint its material in any form.

\title{
Linguistic impoliteness and religiously aggravated hate crime in England and Wales
}

\author{
Jonathan Culpeper, Paul Iganski and Abe Sweiry \\ (Lancaster University)
}

Despite its centrality to religiously aggravated hate crime recorded in England and Wales, the nature of the language used has been neglected in research. This paper, based on a unique dataset, aims to rectify this. It takes its approach from the field of linguistic impoliteness, a field that has yet to consider hate crime. Therein lies our second aim: to consider whether impoliteness notions can be usefully extended to the language of hate crime. In our data, we examine, in particular, conventionalized impoliteness formulae, insults, threats, incitement and taboo words. Whilst we reveal some linguistic support for the way religiously aggravated hate crime is framed in the law and discussed in the legal literature, we highlight areas of neglect and potential ambiguity. Regarding impoliteness, we demonstrate its effectiveness as an approach to this data, but we also highlight areas of neglect in that literature too, notably, non-conditional threats and incitement.

Keywords: impoliteness, hate crime, insults, threats, incitement, taboo words, identity, religion

\section{Introduction}

Compared with the situation in the United States, access to language data relating to the courtroom in the UK is highly restricted. Studies make do with historical data (e.g. Archer 2005), high-profile cases, such as that of Harold Shipman (convicted of multiple murders in 2000), which are occasionally released in the public interest (e.g. Coulthard and Johnson 2007, Chapter 5), or restricted quantities of data whose near anomalous release seems largely due to the whim of an individual judge or other official (e.g. Harris 1984, pers. com.). Our research is based on unique access gained to the Crown Prosecution Service (CPS) records for England and Wales. That permission for this access was given is probably a consequence of the fact that our research constitutes part of a project conducted under the auspices of the ESRC research centre, Corpus Approaches to the Social Sciences (CASS), based at Lancaster University (UK), and supported by a former government home Minister, a senior police officer responsible for hate crime policy, and the Research and Governance Unit of the CPS, amongst others.

Our focus in this paper is on the language manifested as religiously aggravated hate crime. Religiously aggravated hate crime in England and Wales constitutes a relatively recent crime. The Crime, Security and Anti-terrorism Act of 2001 established provisions for religiously aggravated offences, in addition to racially aggravated offences, in response to a backlash of incidents against Muslims in Britain, following the 9/11 terror attacks in the United States. Yet, to date, there has been no scholarly assessment of precisely what language uttered under what circumstance has been deemed to be in violation of that act. This leads to the specific research question we will address: what are the linguistic characteristics of speech deemed by legal authorities in England and Wales as having the potential to be an indicator of religiously aggravated hate crime? We will approach our data with work on linguistic impoliteness (e.g. Culpeper 2011) in mind. Work on impoliteness originally developed as a kind of counterpoint to linguistic pragmatic work on politeness, notably, the classic and oft cited Brown and Levinson 
This is the author accepted manuscript to appear in the Journal of Language, Aggression and Conflict. As such, it is under copyright; the publisher should be contacted for permission to re-use or reprint its material in any form.

(1987). Language that causes offence is very much the business of impoliteness scholarship. However, that scholarship has not hitherto accommodated the language of hate crime. Thus, another question this paper addresses is: can impoliteness notions and frameworks be usefully extended to the analysis of the language of hate crime?

This paper begins with two brief sections. Section 2 considers hate crime as framed by laws in England and Wales and also relevant notions in the field of impoliteness. Section 3 contains a description of our data. The following and longest section, section 4, examines the kinds of impoliteness that constitute religiously aggravated hate crime. In the final section, we consider the kinds of identity attack evoked.

\section{Background: Hate crime, the law and impoliteness}

\subsection{Hate crime in the legal context of England and Wales}

Libraries have been written on the problem of hate speech. But there is a paucity of scholarly analysis of the many actual utterances manifesting racist, religious, or some other type of social identity based hostility, utterances which aggravate and escalate criminal acts into so-called "hate crime". Among the few analyses which seem to have some relation to the project reported in this paper is the foundational work in the field of Critical Race Theory (cf. Delgado 1982; Matsuda 1989). This work focused on the personal and societal wounds inflicted by racist speech, and as a consequence advocated that such speech — and also equivalent "wordless speech" (Matsuda 1989, 2332) — should be treated as a sui generis category of speech for proscription under criminal law in the United States. However, such theorising mostly cited racist hate speech generically in the abstract rather than examined the linguistic characteristics of the actual use of hate speech. Such a trend of focusing on hate speech in the abstract as against actual usage has arguably dominated the scholarly literature on hate speech to date. Even Croom (e.g. 2013), who has made an important contribution to the discussion of racial slurs, focuses on the implications for semantic theory and philosophical aspects of pragmatics; his work is not driven by large-scale empirical analysis of use. Somewhat closer to our project is Asquith (2009), who proposes that hate speech, or 'malediction' to use her preferred term, is central to the majority of hate violence - marking out such violence as a unique form of interpersonal violence $(2009,162)$. Drawing on Austin's (1962) performative speech act theory and also Langton's (1993) speech act theory, she postulates the subordinating and silencing impact of performative malediction in the case of hate speech. In contrast, in our paper we use more recently developed impoliteness notions and frameworks, not to make inferences about the impact of hate speech as Asquith theorised, but to analyze the linguistic characteristics of hate speech which brought the use of particular utterances to be prosecuted under the criminal law in England and Wales as religiously aggravated hate crime.

The provisions of current law in England and Wales on hate crime are usefully summarized in a Law Commission Report (No. 348; May 2014) dedicated to the topic. There are three distinct sets of legal provisions (Section 2.1):

(1) Aggravated offences under the Crime and Disorder Act 1998 ("CDA"), which deal with offences involving racial or religious hostility;

(2) Offences of stirring up hatred under the Public Order Act 1986 ("POA"), which apply to conduct intended, or likely, to stir up hatred based on race, religion and sexual orientation; and 
This is the author accepted manuscript to appear in the Journal of Language, Aggression and Conflict. As such, it is under copyright; the publisher should be contacted for permission to re-use or reprint its material in any form.

(3) Enhanced sentencing provisions under the Criminal Justice Act 2003 ("CJA"), which apply to hostility on the grounds of race, religion, sexual orientation, disability or transgender identity.

Note the keywords "aggravated" and "hostility", notions that are repeatedly used in these laws and indeed the Law Commission Report. Note also the word "intended", which relates to the important issue of "motivation". Finally, it is worth observing that the laws relate to particular social groups. We briefly elaborate on all these aspects below.

Hostility, according to the Law Commission Report (Section 2.7), is not defined in the Crime and Disorder Act 1998, and there is in fact "no standard legal definition". The Law Commission Report (Section 2.7) refers to an "ordinary dictionary definition", which "includes being 'unfriendly', 'adverse' or 'antagonistic'" and "may also include spite, contempt or dislike". In fact, dictionaries vary hugely in their capacity to represent current usage, many being rooted in the etymological meanings of the past. However, even if the dictionary did articulate commonly and currently understood meanings of hostility, they may not be optimal in the context of hate crime. Walters $(2013,49)$ argues that complex, multifaceted acts of hate, including the "more subtle processes of long-term victimization", do not easily fit those common meanings. In addition, ordinary meanings of hostility are likely to encompass a very large set of behaviours, a much larger set than the legal system and enforcement agencies could possibly deal with. The legal solution to this unsatisfactory situation is to put the onus on the court to decide what hostility means and whether it applies: "Ultimately, it will be a matter for the tribunal of fact to decide whether a defendant has demonstrated, or been motivated by, hostility" (Section 2.7). This is not necessarily a perfect solution, of course, as ensuring consistency across cases will be very difficult.

According to the Crime and Disorder Act 1998 (Section 28.1, quoted in the Law Commission Report, 2014, Section 2.3), an aggravated offence is considered to have taken place if either hostility is demonstrated ((a) below) or motivation is proven ((b) below), or both these factors take place:

(a) at the time of committing the offence, or immediately before or after doing so, the offender demonstrates towards the victim of the offence hostility based on the victim's membership (or presumed membership) of a racial or religious group; or

(b) the offence is motivated (wholly or partly) by hostility towards members of a racial or religious group based on their membership of that group.

Regarding what offences might be deemed to involve aggravated demonstrations of "hostility", the Law Commission Report (2014, Section 2.4) offers a list of possibilities. Excluding offences involving physical harm, we are left with "threatening, abusive or insulting conduct", "harassment" and "putting people in fear of violence", all of which could be achieved linguistically. No specific linguistic examples are offered here. Elsewhere in the Law Commission Report, and indeed in the wider literature, the few linguistic examples given are almost always insults. However, the Law Commission Report (2014) offers an interpretation of what constitutes a demonstration of hostility, and includes some linguistic observations:

2.10 The demonstration of hostility will tend to involve words or gestures, but may be manifested in other ways, for example, by wearing insignia such as a swastika or singing 
This is the author accepted manuscript to appear in the Journal of Language, Aggression and Conflict. As such, it is under copyright; the publisher should be contacted for permission to re-use or reprint its material in any form.

certain songs.

2.11 Whether hostility was demonstrated is a wholly objective question. The victim's perception of, or reaction to, the incident is not relevant. Also immaterial is the fact that the defendant's frame of mind was such that, while committing the offence, he or she would have used abusive terms towards any person by reference to other personal characteristics.[...]

2.12 Whether hostility was demonstrated will be a question of fact for the tribunal to decide in light of all the circumstances. In Pal, Simon Brown LJ stated that the use of racially abusive insults will ordinarily be sufficient to prove demonstration of racial hostility.

It should be noted here that the claim that demonstration is a "wholly objective question" seems to be restricted to perceptions of participants at the time of the purported crime, but not the courtroom. Discussing the meaning of "racial group", the Law Commission Report (2014, Section 2.22) comments on the interpretation of words:

Words are to be construed as generally used in the jurisdiction of England and Wales [...] The Court of Appeal has said that it is for the jury to decide whether the use of a particular term is a demonstration of hostility.

This, then, allows for the fact that words and expressions do not have fixed values but vary according to context, though no guidance is given on the contextual issues at stake. Whilst racial insults such as black bastard or Paki might present clearer cases of hostility demonstrated against a racial group to the courts, insults such as bloody foreigners are likely to be more uncertain (Walters 2013, 60, who also cites relevant court cases). And even apparently clear-cut cases might be challenged; Walters $(2013,61)$ notes a claim that black bastard is "'everyday language on the streets of London'".

Walters $(2013,50)$ points out that some commentators have been concerned that the demonstration of hostility, as denoted by (a), is considered sufficient in itself to count as an aggravated offence, as it might "unfairly capture offenders who unthinkingly 'demonstrate' hostility in the 'heat of the moment', but who for all intents and purposes are not bigots or haters". Indeed, in some legal cases the defence has argued that although hostility was demonstrated, it was not intended (Walters 2013, 63). This brings us to the alternative factor for conviction, namely, motivation, as denoted by (b). Motivation is not quite the same as intention: an intention involves a plan to direct actions towards particular ends, whereas motivation involves reasons why one might have the intention. The Law Commission Report (2014, Section 2.18) notes that motivation is probably even more difficult to prove than intention. It suggests that proof may come from "evidence relating to previous conduct or associations" (2014, Section 2.17), including evidence of expressions of racist views or membership of a racist group. The idea, then, is to connect the individual to evidence of an ideology of hate from which motivations might arise. However, Iganski (2008) points out that most hate crimes are not the result of conscious intentions flowing from such ideologies, but arise in local contexts in the 'heat of the moment', often to address a perceived grievance. Interestingly, Walters (2013, 70, original emphasis) argues that what matters is not an intention to be racist or anti-religious but that "the offender intends to express the insult and is aware that to do so will likely demean the victim's identity". 
This is the author accepted manuscript to appear in the Journal of Language, Aggression and Conflict. As such, it is under copyright; the publisher should be contacted for permission to re-use or reprint its material in any form.

Regarding the social groups covered by the legislation, the Crime and Disorder Act 1998 (amended by the Anti-terrorism, Crime and Security Act 2001) allows for prosecutions for a specific list of offences for racially and religiously aggravated offences. The Criminal Justice Act 2003 provides some protection for other groups but not in the same way. It suggests that during the sentencing phase, a court must give an enhanced sentence if an offence was aggravated by a demonstration of hostility towards the victim based on sexual orientation, transgender identity, or disability (or racial or religious group membership). In other words, the "identities" protected by the enactment of 'aggravated offences' are just racial and religious groups, but the other three protected groups get some coverage at the sentencing stage. It should be noted that the notion of "identity" is not operationalised in the laws we have been discussing here, or in the Law Commission Report (2014). 135 instances of the term "identity" out of the total of 170 in that report are simply part of the fixed expression "transgender identity" (a further 14 occur as part of the expression "gender identity", and the remainder relate to sexual orientation). Instead, as we saw in the quotation from the Crime and Disorder Act 1998 (Section 28.1), legal documents simply refer to 'membership' or 'presumed membership' of social group.

\subsection{Linguistic impoliteness}

Our aim in this brief section on linguistic impoliteness is not to offer a complete overview of impoliteness, but to concentrate on aspects of impoliteness relevant to notions raised in the previous section on the language of hate crime in the legal context of the UK.

The notion of hostility is not unknown in the world of impoliteness. In fact, it is part of the label "reasonable hostility" that Tracy (2008) uses to refer to impoliteness (or what she calls "face-attack") in situations where it is considered appropriate. However, there are also many other broadly similar labels used in the literature on linguistic offence, including "rudeness", "incivility", "verbal aggression" and "face-aggravation" (see Culpeper 2011, chapter 1, for a discussion of and references relating to some of these labels), and many more are used outside academia. Each has their own semantic characteristics. Culpeper $(2011,72)$ proposes that the label "impoliteness" is used as a cover term for these related labels, not least because the word "impoliteness" has very little currency and is thus ripe for appropriation as a technical term. This is the policy we adopt in this paper.

Let us pick up on one of the labels just mentioned, the one containing the word "aggravation". Locher and Bousfield (2008, 3), reviewing the contributions to their edited collection on impoliteness, comment that, whilst there is "no solid agreement as to what 'impoliteness' actually is", the "lowest common denominator" seems to be: "impoliteness is behaviour that is face-aggravating in a particular context". The notion of 'face' must qualify as one of the most frequently mentioned concepts in work on impoliteness, especially in earlier work (e.g. Lachenicht 1980; Beebe 1995; Culpeper 1996; Bousfield 2008). It is a technical notion that has helped delineate and operationalize both politeness and impoliteness. It could also help with hostility in the context of hate crime. Most (im)politeness works draw on Goffman (1967: 5) for their definition of face, where it is defined as follows:

the positive social value a person effectively claims for himself by the line others assume he has taken during a particular contact. Face is an image of self delineated in terms of approved social attributes. 
This is the author accepted manuscript to appear in the Journal of Language, Aggression and Conflict. As such, it is under copyright; the publisher should be contacted for permission to re-use or reprint its material in any form.

Note that face in Goffman's definition is not just the positive values that you yourself want, but what you can claim about yourself from what others assume about your actions. This is a crucial point: Goffman's notion of face involves the public mediation of identity. This idea could deepen Walter's $(2013,70)$ argument that the key to hostile insults should be the speaker's awareness that they are likely to demean the victim's identity. From the point of view of face, hostile insults are not about the psychological properties of either the victim or the defendant before the event in question, but about assumptions concerning what might conflict with the kind of positive values (including those involving identity) the victim might want to claim during a particular interaction.

Given that face involves an "image of self", it seems a short-step from discussions of face to discussions of identity. However, the concepts of face and identity have generally been pursued separately, at least until recently, when we see a particular focus on (im)politeness and identity emerging. One might note work such as Spencer-Oatey 2007, Locher 2008 and especially Garcés-Conejos Blitvich e.g. 2009, 2013, along with the special issue on face, identity and (im)politeness in the Journal of Politeness Research, 2013, volume 9, issue 1 (see especially Garcés-Conejos Blitvich, Lorenzo-Dus, and Bou-Franch, 2013), and also the discussion in Blitvich and Sifianou (forthcoming). What is of particular note for the current paper is the increasingly strong acknowledgement, in the light of identity research in particular, that face is not simply the property of an individual. For example, Spencer-Oatey's (e.g. 2008) model of "rapport management", in which she describes politeness, impoliteness and other interpersonal notions, proposed two major types of face: 'quality face' (which encompasses personal qualities, such as intelligence or competence), and 'social identity face' (which encompasses social identities and roles, such as a Muslim or mother). ${ }^{1}$ The latter is obviously of particular relevance to our data.

To the non-academic, it is perhaps a no-brainer that certain words and expressions demonstrate impoliteness. However, this is a site of some dispute in the impoliteness literature. For example, Fraser and Nolen $(1981,96)$ state:

no sentence is inherently polite or impolite. We often take certain expressions to be impolite, but it is not the expressions themselves but the conditions under which they are used that determines the judgment of politeness. (Fraser and Nolen 1981, 96)

And this is echoed by other researchers (e.g. Watts 2003; Locher 2006). To be fair, these researchers were reacting to earlier work which seemed to treat words and expressions as stable vehicles for politeness or impoliteness, and also they do sometimes acknowledge that particular words or expressions lend themselves to particular (im)politeness perceptions. Indeed, people are able to proffer judgements about the degree of politeness of any word or expression even when it is out of context. The explanation for this, as Holtgraves $(2005,89)$ notes, is that "people possess a schematic knowledge regarding language and its social implications, knowledge that exists independent of any occasion of use". The wording is important here: the claim is that it is "independent of any occasion of use" and not that it is independent of context. Words and expressions become increasingly associated with their contexts of use so that those contexts become part of the meanings of those words and expressions with the result that they can be interpreted with the associations of their contexts even when they are used in atypical contexts. This view, broadly speaking, is in tune with Terkourafi's (e.g. 2001, 2002, 2003) proposals about politeness formulae arising as a result of becoming conventionalized for certain contexts of use; and Culpeper (2010) builds on those proposals for similar claims about impoliteness. Note here that there is absolutely no claim that such items have completely stable (im)polite meanings, that 
This is the author accepted manuscript to appear in the Journal of Language, Aggression and Conflict. As such, it is under copyright; the publisher should be contacted for permission to re-use or reprint its material in any form.

they are (im)polite in all contexts of use, but simply that they have default interpretations. Again, this idea is in tune with Walter's $(2013,70)$ argument that the key to hostile insults should be the speaker's awareness that they are likely to demean the victim's identity.

Motivation is not much discussed in the impoliteness literature, although one can find comments on situational factors such as "trigger events" and provocation. However, there is a fairly prominent thread on intentionality in the context of impoliteness, that is to say, where somebody intended to offend, had the requisite skill to carry out offence, hatched a plan to carry out that offence, and then carried it out with full awareness. One reason for this prominence is that it helps distinguish 'genuine' cases from cases where somebody inadvertently caused offence (through, for example, a faux pas). Recollect the concerns mentioned in the previous section with respect to the framing of hate crime law and the possibility of unintentional demonstration of hostility. Regarding impoliteness, consider Bousfield's (2008, 72; our emphasis) definition:

Impoliteness constitutes the communication of intentionally gratuitous and conflictive verbal face-threatening acts which are purposefully delivered: (1) unmitigated [...], and /or (ii) with deliberate aggression [...]

This definition clearly takes the communicator's perspective (i.e. the intention of the communicator in doing X). From the target's point of view, we are actually dealing with perceptions of the communicator's intention. In fact, work on (im)politeness over the last ten years has emphasized the relative importance of what others make of a communicator's intentions compared with what the communicator's intentions might actually have been (e.g. Locher and Watts 2008). One practical issue in tune with this line is that we have no direct way of reaching into the heads of the speakers/communicators to discover what they intended (and sometimes even communicators are not sure what they intended or construct the intention post hoc). Moreover, it emerged in Culpeper's (2011) analysis of 100 narrative reports from British undergraduates of impoliteness events, and also in the work of others (e.g. Gabriel 1998), that sometimes people construe an act as both unintentional and offensive, and also describe it as impolite. Interestingly, Culpeper (2001) argued that whilst the offensive consequences of the utterance might not have been considered intentional, the informant may well have considered them foreseeable, and thus consequences that should have been prevented. This is perfectly in tune with Walker's (2013) argument for awareness and likelihood in hostile insults, as noted above.

\section{The data and method}

\subsection{Data}

We consider CPS case records for all prosecuted cases that were flagged as 'religiously aggravated' in the 2012-13 financial year and tried in the Crown Courts. ${ }^{2}$ In 2012-13, according to records produced for the research by the CPS Management Information Team, 66 cases going before the Crown Courts were flagged as religiously aggravated on the CPS Case Management System, involving 90 defendants in total. Although flagged as 'religiously aggravated', not all of the cases included indictments for religiously aggravated offences. As the aims of our research were to explore the linguistic triggers for the prosecution of religiously aggravated offences, the selection of cases we analyzed was confined to all those with indictments for religiously aggravated offences - representing all prosecutions in the Crown Courts for religiously 
This is the author accepted manuscript to appear in the Journal of Language, Aggression and Conflict. As such, it is under copyright; the publisher should be contacted for permission to re-use or reprint its material in any form.

aggravated offences in 2012-13. Given our interest in the linguistic component of religious aggravation, we also included a small number of cases in which some type of religious aggravation was mentioned in either the indictment or elsewhere in the case records, even though there was not an indictment for a religiously aggravated offence. With these selection criteria, our sample consisted of 17 cases in total. Each case has three sets of documents:

(1) The Report to Crown Prosecutor for Charging Decision (referred to as the MG3 form) capturing the details of the case as reported by the victim(s), any witnesses and police officers along with the defendant's response to the allegations, the rationale for prosecution along with a weighing of the potential strengths and limitations of the prosecution's case.

(2) The Record of Taped Interview (ROTI) providing a transcript of the defendant's interview(s) by the police.

(3) The Indictment detailing the charges faced by the defendant(s) in court.

The quantity of documentation for each case varied considerably. In some cases, 'no comment' interviews provided only a few hundred words for analysis in a ROTI, whilst in others, lengthy interviews extended as long as 11,824 words.

We made no a priori assumptions about whether any particular utterance or behaviour constitutes impoliteness or hate crime, or indeed anything else. It should be noted that we make no claims about the "truth" or "reality" of the crime. Utterances and behaviours appear in the documents because they have been deemed relevant to the crime by a participant, that is, a victim, a witness, a police officer, or sometimes the defendant. It follows, therefore, that we are not getting a full transcript of what was said in the crime scene or a full detailing of the context, but a particular selection. Nevertheless, it is a selection deemed relevant to the law, and, moreover, it is the selection which will be used in the courtroom to decide the verdict. Thus, it is of crucial importance.

\subsection{Method}

This paper is based on the analysis of all the utterances and other communicative behaviours represented in documents identified in section 3.1, and which are (a) alleged to have been produced by the defendant(s) at the scene of the alleged crime, and (b) have at least some claim to being offensive. Identifying and collecting these utterances/behaviours for our dataset was straightforward as they were nearly always marked as direct speech report, as illustrated by example [1] (no attempt is been made to tidy-up, standardize or otherwise adjust the data represented in this paper).

[1] The customer alleged that she was unhappy with the quality of oranges she was seeking to buy and complained to the stall-holder. Allegedly, in response, the stall-holder verbally abused the customer, and by her account, told her to "Fuck off" and called her "You fucking foreign lady".

In addition, we admitted three borderline examples which, though a form of indirect speech report, provided a good idea of the orientation of the utterance in the context of the alleged crime, as illustrated by example [2]. 
This is the author accepted manuscript to appear in the Journal of Language, Aggression and Conflict. As such, it is under copyright; the publisher should be contacted for permission to re-use or reprint its material in any form.

[2] The letters reportedly "The letters attacked the VICTIM's religious beliefs, in particular the use of Tarot Cards and that they were preaching the words of the devil." We do not have available evidence of the actual words used in the letters.

We also included any specific negative behaviours (e.g. spitting, a cutting of the throat gesture).

Our key, though not only, analytical framework was to apply the categories for conventionalized impoliteness formulae identified in Culpeper (2011, chapter 4). A conventionalized impoliteness formula is a regularly occurring bundle of language or a non-verbal sign in which context-specific offensive effects are encoded to a degree. Culpeper (2011) initially identified the various types of impoliteness formulae by studying discourses in which impoliteness is central (e.g. army training, exploitative TV shows, graffiti), drawing on a varied collection of data accumulated over 15 years. The limitation of these contexts is that they reflect contexts which are either institutional or often at least partly contrived; they do not include those more everyday moments of impoliteness - on the bus, with a shop assistant, with a member of your family, and so on. So, in addition, Culpeper (2011) deployed an impoliteness event report form filled in by 100 British undergraduates. Having thus generated a range of impoliteness types, the next step taken was to establish whether these formulae are regularly associated with impoliteness effects, and thus can be claimed to be conventionalized. Culpeper (2011) checked all items in the two-billion word Oxford English Corpus (see: http://www.oxforddictionaries.com/words/the-oxford-englishcorpus), in order to make sure that more than $50 \%$ of the instances of each type occurred in contexts which could be interpreted as involving impoliteness. The resulting list of formulae that met this criterion is displayed in Table 1 (further information about the formulae can be found in Culpeper 2011: chapter 4).

Table 1. Conventionalized impoliteness formulae (drawn from Culpeper 2011, 135-136)

\begin{tabular}{|l|l|}
\hline Impoliteness formulae type & Example \\
\hline Insult (Personalised negative vocatives) & you fucking moron \\
\hline Insult (Personalised negative assertions) & you are such a bitch \\
\hline Insult (Personalised negative references) & your little arse \\
\hline $\begin{array}{l}\text { Insult (Personalised third-person negative references in the hearing } \\
\text { of the target) }\end{array}$ & the daft bimbo \\
\hline $\begin{array}{l}\text { Pointed criticisms/complaints } \\
\text { Challenging or unpalatable questions and/or presuppositions }\end{array}$ & that is total crap \\
\hline Condescensions & why do you make my life impossible \\
\hline Message enforcers & that's being babyish \\
\hline Dismissals & listen here \\
\hline Silencers & fuck off \\
\hline Threats & shut the fuck up \\
\hline Curses and ill-wishes & $\begin{array}{l}\text { I'm going to bust your fucking head off if you } \\
\text { touch my car }\end{array}$ \\
\hline
\end{tabular}

Some items that one might expect to be in Table 1 simply did not occur frequently enough. For example, taboo words can trigger a judgement of impoliteness, but they seem to do this per se rarely - a mere two cases out of 100 in Culpeper's $(2011,136)$ report data. In most cases, taboo words operate in conjunction with impoliteness formulae such as those in Table 1. Also, we should note that, whilst Culpeper (2011) acknowledges the existence of conventionalized non-verbal impoliteness behaviour (e.g. spitting, a two or one fingered gesture), he does not investigate them. 
This is the author accepted manuscript to appear in the Journal of Language, Aggression and Conflict. As such, it is under copyright; the publisher should be contacted for permission to re-use or reprint its material in any form.

We then coded and segmented our dataset with the categories comprising conventionalized impoliteness formulae. This was a relatively simple process, as most of the data are reported as fragments of direct speech which neatly fit a category. For instance, in example [1], "fuck off" is a Dismissal, and "You fucking foreign lady" is an Insult (specifically, the variant that comprises personalised negative vocatives). If an utterance/behaviour repeated an impoliteness formula (e.g. "fuck off, fuck off"), each received a separate coding. If the utterance/behaviour ran together a mix of impoliteness formulae (e.g. "fuck off you fucking foreign lady"), each received a separate and different coding. As we elaborate in the following section, just a small number of utterances/behaviours did not fit the categories of conventionalized impoliteness, but instead relied on the generation of impolite implications. Our dataset comprises 168 codings in total. The upcoming sections will note the relative proportions the different types of impoliteness consume of that 168 , and also examine their nature more closely.

\section{The building blocks of the language of hate crime}

\subsection{Prefabricated or creative?}

Our first goal was to establish whether the language of our data is comprised of language associated with impoliteness contexts; in other words, whether it is comprised of language more likely to offend, that is, conventionalized or pre-fabricated impoliteness formulae. 89.3\% (149) of our dataset were coded conventionalized impoliteness formulae. Our data is indeed regularly associated with impoliteness. Interestingly, our figure of $89.3 \%$ is more than double the figure of $41 \%$ for impoliteness events reported by British students in Culpeper $(2011,155)$. Why is there this difference?

Relying primarily on pre-fabricated chunks held in memory involves less mental effort. It is less creative. Creativity in impoliteness tends to go hand in hand with entertaining functions of impoliteness and often social solidarity functions, as is frequently the case with banter (Culpeper 2011, 207-215, 233-244). One might reasonably expect less thought-full language production in the typical situations of our data, that is, highly emotional and stressful situations. However, we cannot ignore another factor that may have a bearing: impoliteness that is more explicit - a conventionalized formula - is more likely to get reported than impoliteness that is more implicational in nature. Consider this utterance that was reported in our data:

\section{[3] See you next Saturday.}

Superficially, it is innocuous, but the context allows an offensive interpretation. It was allegedly said by a defendant to the victim(s) as he was taken away by police. Significantly, he is alleged to have regularly turned up on Saturdays to harass the victim(s). Hence, there is an implied threat to do the same next Saturday. Such cases tend not to get reported, because they are usually more complex and do not fit the discussions surrounding the law which focus on "words" and "terms" imbued with hostility (see section 2.1). Whether such implicational cases can cause as much or even more offence than conventionalized formulae has not been the subject of sufficient research.

\subsection{The hate crime language mix: Coercive impoliteness}

Despite the obvious centrality of language to the manifestation of hate crime, the law, as noted in section 2.1, offers little indication as to nature of relevant language. Figure 1 displays the 
This is the author accepted manuscript to appear in the Journal of Language, Aggression and Conflict. As such, it is under copyright; the publisher should be contacted for permission to re-use or reprint its material in any form.

percentages and frequencies with which different types of conventionalized impoliteness formulae appear in our data.

Figure 1. Types of impoliteness formulae(the $\mathrm{Y}$ axis indicates raw frequency; the percentages on top of each bar indicate the proportion of the category with respect to the total 149 items that are conventionalized impoliteness formulae)

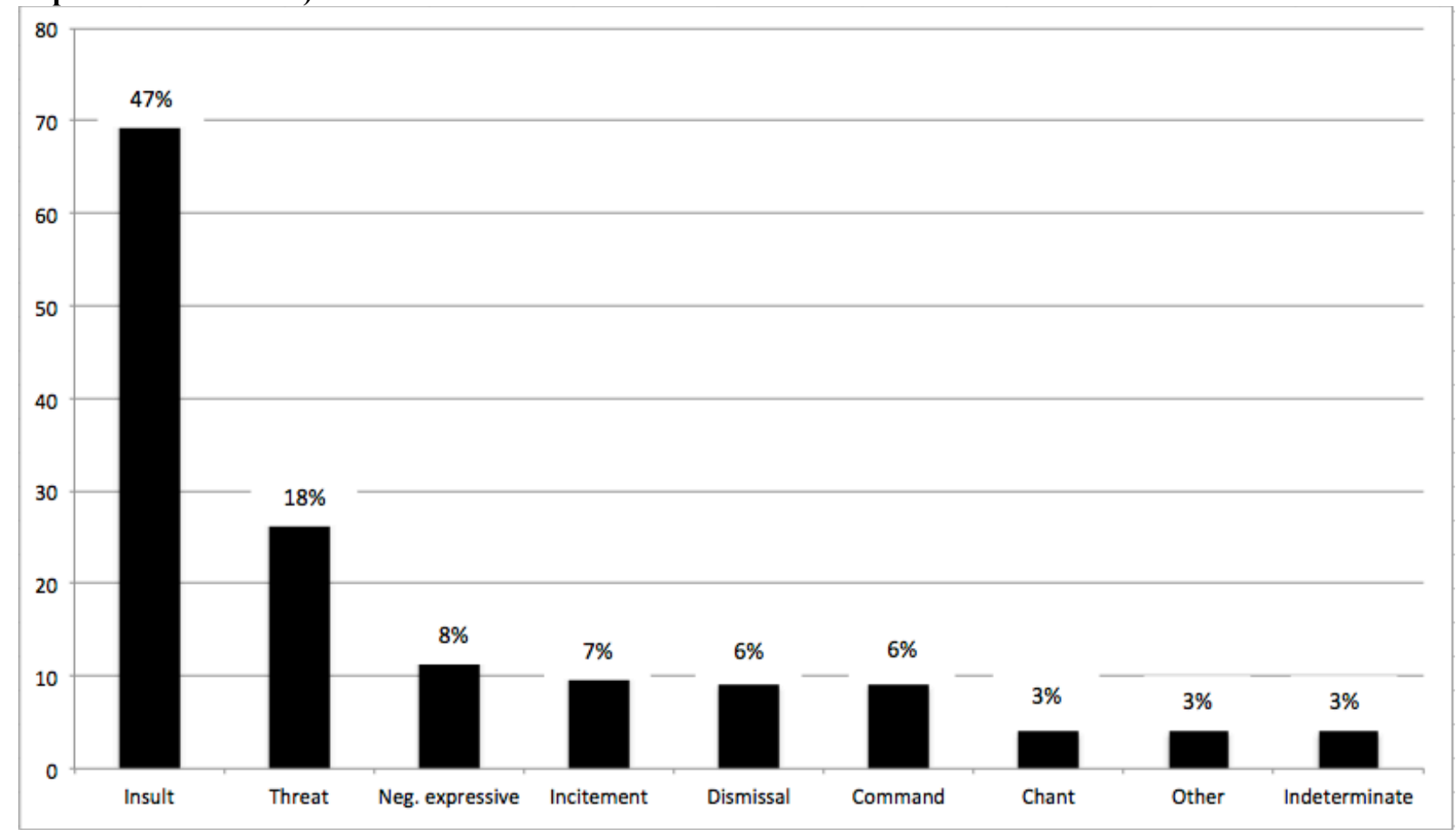

Insults and threats are typical of coercive impoliteness (Culpeper 2011, 225-233), that is, "impoliteness that seeks a realignment of values between the producer and the target such that the producer benefits or has their current benefits reinforced or protected" $(2011,252)$. Culpeper's notion of coercive impoliteness was partly modelled on work on aggression in social psychology, especially Tedeschi and Felson (1994). Consider their definition of a coercive action:

A coercive action is an action taken with the intention of imposing harm on another person or forcing compliance. Actors engaged in coercive actions expect that their behaviour will either harm the target or lead to compliance, and they value one of these proximate outcomes. The value they attach to compliance or harm to the target arises from their belief about the causal relationship between compliance or harm and the terminal values. There are many values that might be pursued through coercive means. For example, actors might value harm to the target because they believe it will result in justice, or they might value the target's compliance because they believe it will lead to tangible benefits.

There are two aspects of this definition that are particularly relevant to our data. First, coercive action is not merely a matter of forcing behavioural compliance, but includes the notion of social harm, which involves "damage to the social identity of target persons and a lowering of their power or status" and "may be imposed by insults, reproaches, sarcasm, and various types of impolite behaviour" (Tedeschi and Felson 1994,171). It is about using impoliteness to reduce the target's relative symbolic power (Bourdieu 1991), thereby boosting the speaker's symbolic benefits 
(which in turn may lead in the future to material benefits). Second, the specific example of the motivation for harm, namely, that it will result in justice, fits a strong thread in our data. The realignment of values attempted in our data sometimes seems to be perceived as having moral backing, as being a matter of re-balancing things, of redressing a grievance. As noted in section 2.1, redressing a grievance has been mentioned as a motivation for hate crime. Tedeschi and Felson $(1994,218)$ refer to the notion of "distributive justice", which concerns "a fair allocation of benefits, a fair distribution of responsibilities, and recognition of performance or effort", and note that violations of this notion "may form the basis of a grievance and lead to coercive interactions". Example [4] illustrates this, and also the fact that the basis of the grievance need not have common-sense logic (all data examples in this paper follow the spellings and typographical style, e.g. the use of capitals, of the original).

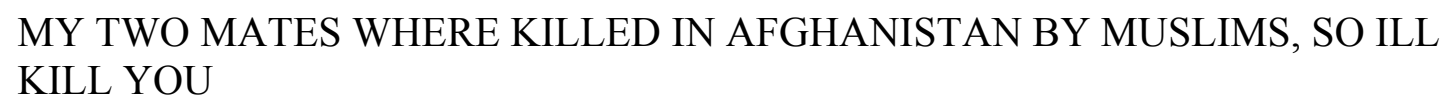
KILL YOU

In fact, the perceived moral backing underpinning the grievance seemed to empower the defendants. In one police interview, the defendant, a member of the English Defence League (EDL), an extremist nationalist right-wing group, defends his actions by alluding to the alleged prior burning of poppies (a symbol to commemorate the death of British and Commonwealth soldiers after the First World War) by Muslim groups (DS = the police officer rank of detective sergeant):

[5] DS SURNAME: What's your feelings about, how do you feel about going to a place of worship and abusing with violence the people in the, in the mosque?

FORENAME SURNAME: How do you feel about them burning poppies?

The following sub-sections focus on the most frequent types of impoliteness formulae in our data, and then considers how they are intensified.

\subsection{A focus on insults}

As mentioned in Section 2.1, if discussions surrounding hate crime mention the language involved, they strongly gravitate towards insults. Given their high frequency of occurrence in Figure 1, constituting $47 \%$ of the conventionalized impoliteness formulae and more than double any other category, this is justified. Also, as we will see in section 5, they are a convenient linguistic carriage for connecting something negative with group membership. However, not all insults are the same. Almost all the insults in the data are of two types, as illustrated below:

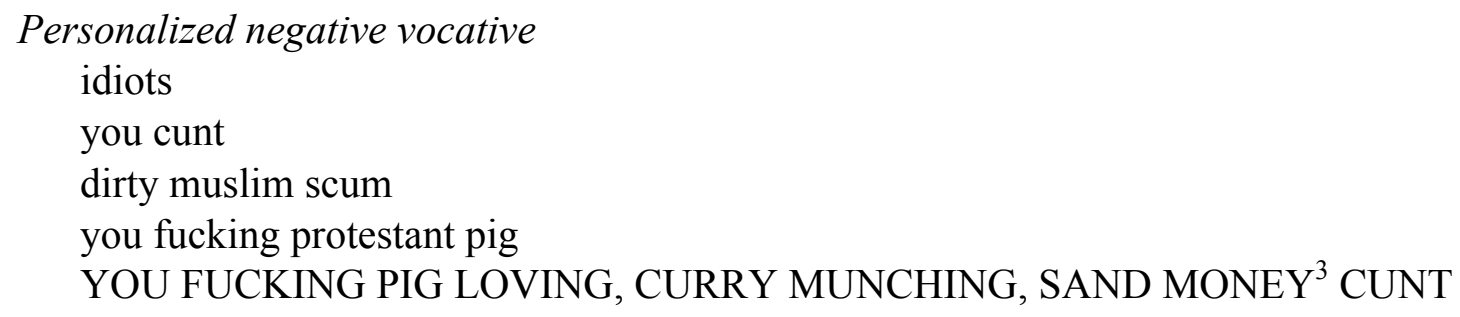

Personalized negative assertion 
This is the author accepted manuscript to appear in the Journal of Language, Aggression and Conflict. As such, it is under copyright; the publisher should be contacted for permission to re-use or reprint its material in any form.

you are a terrorist

you're a fucking Muslim

You don't answer coz $u$ no $u$ lowest of the low

The fact that these were the most frequent types of insult is not at all distinctive of our data; the datasets examined in Culpeper (2011) also had a preponderance of these types. What is distinctive about the data is that five of the reported insults involved alleged behaviours rather than speech, including: spitting and urinating at a mosque, tearing pages out of the Koran and throwing it down in front of the victims, and pulling-off the victim's head scarf and throwing it on the floor. Just as with verbal insults, such behaviours are symbolic violations of identities.

The fact that insults are the predominant type of impoliteness in our data by far (more than twice as frequent as threats, for example) is a distinctive feature of our data. For instance, Kleinke and Bös (2015) studied impoliteness in the BBC's forum Have Your Say, using some of the same impoliteness categories as those used in this paper (i.e. from Culpeper 2011). They discovered that 'pointed criticism' was the most dominant category, accounting for $21 \%$ of their impoliteness 869 codings $(2015,56)$, even exceeding insults. In contrast, this category does not appear in our data. Example [7] illustrates pointed criticism.

[7] Catholicism is responsible for maliciously keeping half of the worlds population in poverty (Kleinke and Bös 2015, 55)

A key difference between insults and pointed criticism is personalization, usually achieved explicitly through the use of second person pronouns. Insults typically target the addressee's face, or phenomena (e.g. group membership) in which they have face invested; pointed criticism targets a third party. However, there is leakage between these types of impoliteness. Compare examples [8] and [9], both from our data:

you're a terrorist

[9] the Islamic religion is bullshit (addressed to Islamic victim)

"You're a terrorist" is obviously an insult: the use of the second person pronoun picks out the target; that target is associated with what is widely viewed as a repugnant group, terrorists, and thereby their face is potentially violated. "The Islamic religion is bullshit" denigrates the Islamic religion, and if the target has face invested in it, then their face is potentially violated.

Superficially, example [9] looks like the pointed criticism of example [7]: both make a negative claim about a religion. However, the difference in context is crucial. [9], "The Islamic religion is bullshit", although not explicitly marked by a second person pronoun, is alleged to have been addressed to the Muslim victims present in the physical situation in which it was said. In other words, it implicitly targets those addressees. In contrast, [7], "Catholicism is responsible for maliciously, etc", is said in a context where the presence of Catholics is not salient. Of course, there is potential for leakage between these two impoliteness types. For example, if a Catholic happened to be in the communicative context of example [7], it is quite possible that they may have taken that utterance as an insult, rather than pointed criticism. The context then is crucial. Moreover, in a legal context, the difference is significant. A possible defence could be that it was not an insult, just a pointed criticism. A religiously-oriented insult clearly breaks the law: "the offender demonstrates towards the victim of the offence hostility" (see section 2.1; our emphasis). 
This is the author accepted manuscript to appear in the Journal of Language, Aggression and Conflict. As such, it is under copyright; the publisher should be contacted for permission to re-use or reprint its material in any form.

Religiously-oriented pointed criticism does not. Whilst the court records sometimes include indications as to the direction of talk (e.g. "at the victim"), often this is matter of inference based on what is reported of the context. This puts pressure on the adequacy of the record for reporting context.

\subsection{A focus on threats}

Threatening conduct is associated with hate crime, and so it is no surprise to see threats as the second most frequent formula. However, the particularly important point is that those in our data are distinctive. Culpeper $(2011,136)$ identifies three structures for threats in impoliteness contexts, the most frequent being given in example [10] (the example is constructed out of his data to display prototypical components constituting the threat):

[10] [I'll/I'm/we're] [gonna] [smash your face in/beat the shit out of you/box your ears/bust your fucking head off/straighten you out/etc.] [if you don't] [X]

All structures studied in that work are conditional threats. Similarly, Limberg (2009), a paper that deals with impoliteness and threats, especially responses to threats, focuses on conditional threats, confining non-conditional threats to very occasional brief remarks. In contrast with these studies, our data contain no conditional threats. Instead, our data contain: (1) 26 non-conditional threats, (2) one action characterized as a threat (allegedly, somebody making a shooting gun motion at the victims), and (3) 8 implied threats (e.g. "you're all fucking dead" ${ }^{4}$ ). Example [11] illustrates a nonconditional threat.

\section{[11] I'm gonna kill you and your family}

Holger $(2009,1382)$ remarks that the "implication that the addressee draws from a conditional threat utterance allows him/her to correct the behavior and/or comment on the implicit reproach". Non-conditional threats offer no such explicit opportunities for correction. If there is implicitly an issue associated with the non-conditional threats in our data that needs correction, it would likely be a grievance, as mentioned in section 2.2 . In fact, conditional threats are more like commands, controlling the addressee's future action; non-conditional threats, as in our data, express a commitment to harm the addressee in the future (see the discussion in Martínez-Cabeza 2009). It should be noted, however, that the future orientation of threats just described is present in the semantics, rather than the effect of the act. A perlocutionary effect, to use speech act terminology (e.g. Austin 1962), of a threat, whether conditional or non-conditional, is intimidation. This takes place at the point of utterance, not in the future. This clearly fits the framing of the law, notably of "putting people in fear of violence" (Section 2.2).

\subsection{A focus on incitement and negative expressives}

Incitement was not mentioned in section 2.1 because it is not mentioned in the laws outlining offences of religious aggravation, nor in the offences that can be subject to aggravation, as suggested in the Law Commission Report (2014, Section 2.4). It is discussed at some length, however, in the Law Commission Report (2014, 2.33-56) under the heading "The Stirring up offences", the focus being whether incitement to religious hatred being explicitly included in the law relating to religiously aggravated hate crime is desirable and the extent to which it might 
This is the author accepted manuscript to appear in the Journal of Language, Aggression and Conflict. As such, it is under copyright; the publisher should be contacted for permission to re-use or reprint its material in any form.

already be covered in other laws. As far as the impoliteness literature is concerned, incitement appears nowhere.

Paradigm examples in our data include:

[12] [shouted] let's kill him

\section{[13] GET THEM OUT OF OUR COUNTRY}

As these examples illustrate, such utterances involve hortative or imperative constructions. The notion of incitement raises interesting issues for speech act theory (e.g. Austin 1962), and has been discussed at length in legal studies. Kurzon (1998) usefully discusses incitement in the contexts both of speech act theory and the law. We will not rehearse such discussions in detail, but raise some of the relevant complexities aired, especially as they apply to our data.

In the USA, a touchtone for the discussion of incitement is the First Amendment and its provisions for the protection of free speech. A particularly important case is Brandenburg vs Ohio (1969). Here, the Supreme Court overturned the conviction of Brandenburg, a member of the Klu Klux Klan, who had been charged under Ohio state law. They overturned the conviction because the utterances at issue were considered "mere advocacy" rather than "incitement to imminent lawless action" (395 U.S. 444; see: https://www.law.cornell.edu/supremecourt/text/395/444). Not surprisingly, this rather tenuous distinction has stimulated much legal discussion (e.g. how imminent must imminent action be to be considered so?). What interests us here are the actual utterances in the case. They included "Send the Jews back to Israel" and "Bury the niggers" ostensibly, exactly the same kind of utterances as those of our data. However, there are differences in the contexts in which these were said, and therefore differences in the potential range of effects. Brandenburg reportedly made those utterances at a Ku Klux Klan meeting; in other words, amongst like-minded people. The utterances in our data which we have labelled incitement were made, as far as we can work out, in the hearing of the victims. Moreover, not only is fairly immediate lawless action (e.g. assault) possible, but - and this is the key point - the mere expression of such utterances potentially causes immediate social harm by instilling fear in the victims. Similar to threats, the effect is one of intimidation. Note here that cases such as these require a complex view of speech acts, such as that articulated in the pioneering work of Thomas (1995) (see especially p. 195-207).The inciter, addressing an accomplice, may perform an act of incitement which indirectly is intended as and/or taken to be a threat by a bystander (victim).

This is not to say that all of our examples are unambiguously examples of incitement. Consider example [14]:

Fuck the Koran

This is ambiguous between an incitement to inflict physical harm, as might be more transparently conveyed by "Let's fuck up the Koran" (note here that one of our cases concerned tearing pages out of the Koran), and an expression of negative feelings, as might be more transparently conveyed by "I don't give a fuck about the Koran". Both, of course, are highly offensive, targeting a key symbol of a religion, though not in the same way. Compare [14] with [15], which was allegedly spoken by a Scotsman to English police officers:

[15] Fuck the Queen 
This is the author accepted manuscript to appear in the Journal of Language, Aggression and Conflict. As such, it is under copyright; the publisher should be contacted for permission to re-use or reprint its material in any form.

It is of course improbable that in this context this could be anything other than the expression of negative feelings - not only is the idea of causing physical harm to the Queen a rather remote possibility, but the target audience, English police officers, constitute unlikely candidates for incitement to cause physical harm. Instead, it is the expression of negative feelings, targeting the identities of the English police officers by orienting an attack to the symbolic figurehead of their nation state. In order to reinforce the argument in this paragraph, one might reflect on the meaning of [13] had it been said in England a little over 400 years ago during the reign of Elizabeth I. At that time, in the context of national paranoia about plots to overthrow and/or assassinate the Queen, an incitement reading would be more probable.

\subsection{Intensification: Taboo words}

Young's $(2004,300)$ research on 'hurtful communication' reveals that:

How the message was stated was pivotal in determining recipients' appraisals of it. Comments that were stated harshly, abrasively or that used extreme language were likely to be viewed more negatively.

One of the most striking features of our data is the high density of taboo words. $50.3 \%$ of the conventionalized impoliteness formulae( or 75 of the 149) used at least one taboo word. Compare this with Culpeper's $(2011,136)$ finding that only two of his 100 impoliteness events recorded by students as diary reports contained taboo words. The taboo words in our data are not only frequent but dominated by those perceived to be most offensive in Britain. Perhaps the most substantial study of people's attitudes to taboo words and offensive language, and also the role of context, in Britain is Millward-Hargrave (2000). Involving a questionnaire delivered to 1,033 informants, this study was commissioned jointly by the Advertising Standards Authority, the British Broadcasting Corporation (BBC), the Broadcasting Standards Commission and the Independent Television Commission. Table 1 displays the offensiveness rankings of taboo words in Millwood-Hargrave (2000) and their frequency in our data:

Table 2. Taboo words and their offensiveness in religiously aggravated hate speech

\begin{tabular}{|l|l|l|}
\hline $\begin{array}{l}\text { Taboo word in our } \\
\text { data }\end{array}$ & $\begin{array}{l}\text { Millward-Hargrave's } \\
\text { (2000) offensiveness } \\
\text { ranking }\end{array}$ & $\begin{array}{l}\text { Frequency in our } \\
\text { data }\end{array}$ \\
\hline cunt & 1 & 11 \\
\hline fuck-related & $2 / 3$ & 53 \\
\hline nigger & 5 & 2 \\
\hline paki & 10 & 5 \\
\hline mildly taboo words & $17+$ & 13 \\
\hline
\end{tabular}

Culpeper $(2011,136)$ argues that in most cases taboo words operate in conjunction with impoliteness formulae in order to exacerbate them. This kind of intensification is likely to be represented in our records, but we should not forget that impoliteness is often intensified by features less likely to appear in our records, namely, prosody (e.g. wide pitch range, sharp pitch falls, high amplitude) and non-verbal behaviours (e.g. spitting, two or one fingered gestures, anger displays). However, we should bear in mind that simple intensification is not the only function 
This is the author accepted manuscript to appear in the Journal of Language, Aggression and Conflict. As such, it is under copyright; the publisher should be contacted for permission to re-use or reprint its material in any form.

performed by taboo words. Example [16] illustrates some of the diversity possible with fuckrelated taboo words.

[16] I'm a fucking DOUGLAS, so don't you fucking fuck with me

Table 3 shows the functions and structures of fuck-related taboo words in our data and their frequencies.

Table 3. Fuck-related taboo words in religiously aggravated hate crime language: Forms and functions $[\mathrm{NP}=$ noun phrase; $\mathrm{VP}=$ verb phrase; $\mathrm{ADJ}=$ adjective; $\mathrm{ADV}=$ adverb; $\mathbf{P P}=$ prepositional phrase $]$

\begin{tabular}{|l|l|l|l|}
\hline Function & Structure & Example & Freq. \\
\hline Intensifying elements & fucking NP & you fucking mug & 21 \\
\cline { 2 - 4 } & fucking VP & we fucking hate Muslim scum & 5 \\
\cline { 2 - 4 } & fucking & fucking & 2 \\
\cline { 2 - 4 } & fucking ADJ & you're all fucking dead & 1 \\
\hline & & & 10 \\
\hline Negative expressives & fuck NP & fuck you & \\
\hline & & & 3 \\
\hline Threats & don't fuck with NP & don't fuck with me & 2 \\
\hline & fuck you [ADV] up & fuck you right up & \\
\hline & fuck up NP & ready to fuck up Muslim scum & 1 \\
\hline & & & 5 \\
\hline Dismissals & fuck off [PP] & fuck off back to the desert & 5 \\
\hline & & & 2 \\
\hline Idiomatic expressions & give a fuck & I don't give a fuck & 2 \\
\hline & fucking hell & fucking hell & 53 \\
\hline TOTAL & & & \\
\hline
\end{tabular}

As can be seen, the intensifying function is indeed the most frequent for fuck-related elements, and most often plays a role in insults (which are typically of the form "fucking NP"). However, that function only accounts for a little over half of the instances. Amongst the other functions, negative expressives (prototypical instances being curses) constitute the most prominent type.

\section{Identity attacks}

$39.9 \%$ (or 67) of the total 168 coded utterances/behaviours in our data explicitly target an aspect of the addressee's group identity, almost always through an insult. 64.2\% (43) of these identity attacks explicitly target a religious aspect of the addressee's identity. This is $25.6 \%$ of all coded utterances/behaviours. It may seem puzzling that a mere quarter of the utterances/behaviours explicitly involve identity, as our data were selected on the basis that they allegedly violated the law with respect to religious identity (see Section 2.1). What these numbers reveal is that, although every case in our data contains at least one religious identity attack, other kinds of impoliteness dominate. We can infer from this that religiously aggravated hate crime events seldom revolve around the performance of the language of religiously aggravated hate crime alone, but normally 
This is the author accepted manuscript to appear in the Journal of Language, Aggression and Conflict. As such, it is under copyright; the publisher should be contacted for permission to re-use or reprint its material in any form.

are constituted by multiple impoliteness utterances/behaviours, of which religiously aggravated hate is one. Other group membership identities attacked include race, nationality, gender and sexuality. The remaining utterances /behaviours explicitly target personal identity aspects and values (e.g. "you bald cunt") or are types of impoliteness which include no explicit identity element (e.g. threats, dismissals and commands).That all these types of impoliteness are recorded in our records is a consequence not only of their relevance as the context to religiously aggravated offences, but also the fact that they may be violating other laws in their own right (e.g. the Protection from Harassment Act 1997; the Public Order Act 1986). For example, as well as charges for religiously aggravated offences, 3 of the 17 cases also included charges for racially aggravated offences.

It is extremely difficult to quantify the actual or perceived religions of key parties. This information does not form part of CPS case documentation, but has to be inferred from comments participants make. For this reason, we cannot give information about general trends regarding participants' religious identities (or indeed any other aspect of identity). However, it is clear that the notionof a non-Muslim attacking a Muslim, which seemed to be the motivation for the development of the relevant legal framework in the first place (see Section 2.1), does not always apply. Other cases involved defendants and victims who were members of:

\author{
Different Christian subgroups: Catholic (by implication) and Protestant \\ Different Islamic subgroups: Shia, Sunni \\ Occultism
}

There was also one case of a Muslim allegedly attacking a non-Muslim. Clearly, this is an area that could benefit from more comprehensive research.

\title{
6. Conclusions
}

This is the first thorough linguistic treatment of speech manifesting as religiously aggravated crime in England and Wales, being, as it is, based on a unique data set. The laws of England and Wales framing and surrounding religiously aggravated hate crime, and also the related legal literature, contain no linguistic detail about what is involved, despite the fact, as noted in our data set, that language is central to the crime. From the perspective of impoliteness, we might add that that literature is not accustomed to dealing with such extreme data, something which adds additional interest to the fact that our approach involved impoliteness concepts and frameworks.

We established that such hate crime is dominated by pre-fabricated conventionalized impoliteness formulae. This lends support to both assumptions in the law and arguments in the legal literature (e.g. Walters 2013) that hate crime can be framed in terms of material that is more "likely" to cause offence. In addition, such impoliteness formulae may reflect a more 'mind-less' kind of impoliteness characteristic of highly emotionally charged situations, though we cannot discount the fact that it may also reflect a tendency for more implied kinds of impoliteness to be recorded less. Our analysis supports the legal literature's focus on insults. They are by far the most numerous act of impoliteness in relation to hate crime, offering a convenient carriage for connecting group identity membership with negative aspects. Moreover, we revealed that they primarily take the form of personalised negative vocatives (e.g. "you X") or personalized negative assertions (e.g. "you are an X"). A danger with the latter, we argued, is that they can blur into pointed criticism, with its rather different legal status, when the target is not made explicit (e.g. "the $\mathrm{Y}$ religion is $\mathrm{X}$ " in the presence of people of $\mathrm{Y}$ religion). The onus is placed on the legal 
This is the author accepted manuscript to appear in the Journal of Language, Aggression and Conflict. As such, it is under copyright; the publisher should be contacted for permission to re-use or reprint its material in any form.

record to adequately represent the context, i.e. who the likely implicit targets are.

However, we also showed that religiously aggravated hate crime events do not just revolve around insults. We revealed that one of the most striking features of our data is that its numerous threats are never conditional threats, as is typical of many other impoliteness datasets, but are nonconditional threats. We argued that despite expressing a future action (e.g. "I'll X you"), the key effect of intimidation is immediate: they put the target in fear of violence. Similarly, we argued that incitement, achieved via imperative or hortative structures, despite expressing a future action, has the immediate effect of intimidation. Interestingly, incitement, though fairly frequent in our data, is not part of the key laws dealing with religiously aggravated hate crime, nor, in fact, is it mentioned anywhere in the impoliteness literature. We also noted the potential for some ambiguities between incitement and negative expressives (e.g. "Fuck X"). Finally, we revealed that a characteristic of almost half of our impoliteness items is that they contain a taboo word, and moreover taboo words that are strongly offensive. They are typically deployed to intensify the impoliteness of insults, to maximise the offensiveness of the message, but they perform some other functions in our data too (e.g. negative expressives such as curses).

Although religious identity is targeted in each of the 17 cases of our data, only a quarter of all reported impoliteness utterances/behaviours involve religious identity. This lends support to the argument that religiously aggravated hate crime events are constituted by many types of impoliteness of which just some relate to religion. Other group membership identities attacked in during those events include race, nationality, gender and sexuality. Yet, we might note that the legal provisions for the protection of these groups vary considerably (gender, for example, is not well accommodated). The remaining utterances /behaviours not involving group membership identities explicitly target personal identity aspects and values (e.g. "you bald cunt") or are types of impoliteness which include no explicit identity element (e.g. threats, dismissals and commands). The fact that our data includes the performance of so many impoliteness utterances/behaviours outside the purview of religiously aggravated hate crime is consistent with the idea that it often arises in the 'heat of the moment' rather than as a conscious intention to be anti-religious, racist, etc. (Iganski 2008). This is not to say, of course, that ideology is not at play. This can most clearly be seen in our data in the idea that a key motivation for hate crime is to redress a grievance (Iganski 2008). The way this idea connects with our analysis begins with the observation that our data is dominated by insults and threats, the stuff of coercive impoliteness, and that participants sometimes evoked moral backing for their coercive actions: they consider themselves to be redressing a "wrong". We noted that this fits the notion of distributive justice (Tedeschi and Felson 1994, 218). What counts as a 'fair' distribution of resources and values is shaped by ideologies concerning religion, ethnicity, etc.

Turning to impoliteness, we have thoroughly demonstrated that impoliteness notions and frameworks are effective in describing and theorizing religiously aggravated hate crime. In some ways this is not surprising because, although hitherto unconnected, they share many similar issues, as elaborated in section 2.2. Even some specifics are shared, such as the recent movement away from full intention to a concern with the awareness of the likelihood of the offensive effects of a particular usage (Walters 2013) or a concern with its foreseeability (Culpeper 2011). However, on occasion in our data we have encountered phenomena that have been almost completely ignored by the impoliteness literature. The stand-out cases of this are non-conditional threats and incitement. More generally, one uncomfortable feature of bringing impoliteness to bear concerns nomenclature. Although, as we stated in section 2.2, we have been using "impoliteness" as a blanket-term for offensive behaviours, we cannot deny that that term suggests coverage of behaviours causing lesser offence than the ones typical of hate crime. Rudanko (2006) suggested 
This is the author accepted manuscript to appear in the Journal of Language, Aggression and Conflict. As such, it is under copyright; the publisher should be contacted for permission to re-use or reprint its material in any form.

the category of "aggravated impoliteness" to address this problem. Certainly, the material in our data must be a prime candidate for such a category.

\section{Acknowledgment}

The research presented in this article was supported by the UK's Economic and Social Research Council (ESRC) Centre for Corpus Approaches to Social Science, ESRC grant reference $\mathrm{ES} / \mathrm{K} 002155 / 1$. This publication is based on datasets, which for ethical and legal reasons cannot be publicly shared.

\section{References}

Archer, Dawn. 2005.Questions and Answers in the English Courtroom (1640-1760): A Sociopragmatic Analysis (Pragmatics \& Beyond New Series 135). Amsterdam and Philadelphia: John Benjamins.

Asquith, Nicole. 2009. "The Harms of Verbal and Textual Hatred Hate Crimes: The Consequences of Hate Crime." In Hate Crimes: The Consequences of Hate Crime, edited by Paul Iganski, Westport, 161-173. Westport, CT: Praeger.

Austin, John L. 1962. How to Do Things with Words. Oxford: Oxford University Press.

Austin, John L. 1962/1975. ( $2^{\text {nd }}$ edn.) How to do Things with Words. Edited by J. O. Urmson and Marina Sbisà. Cambridge, MA.: Harvard University Press.

Beebe, Leslie M. 1995."Polite Fictions: Instrumental Rudeness as Pragmatic Competence." In Linguistics and the Education of Language Teachers: Ethnolinguistic, Psycholinguistics and Sociolinguistic Aspects. Georgetown University Round Table on Languages and Linguistics, edited by James E. Alatis, Carolyn A. Straehle, Brent Gallenberger and Maggie Ronkin, 154-168. Georgetown: Georgetown University Press.

Bourdieu, Pierre. 1991. Language and Symbolic Power. Cambridge: Polity Press.

Bousfield, Derek. 2008. Impoliteness in Interaction. Philadelphia and Amsterdam: John Benjamins.

Brown, Penelope, and Stephen C. Levinson. 1987. Politeness: Some Universals in Language Usage. Cambridge: Cambridge University Press.

Coulthard, Malcolm, and Alison Johnson. 2007. An Introduction to Forensic Linguistics: Language in Evidence. London: Routledge.

Croom, Adam M. 2013. "How to Do Things with Slurs: Studies in the Way of Derogatory Words." Language and Communication 33 (3): 177-204. doi:10.1016/j.langcom.2013.03.008

Culpeper, Jonathan. 1996."Towards an Anatomy of Impoliteness." Journal of Pragmatics 25: 349367. doi:10.1016/0378-2166(95)00014-3

Culpeper, Jonathan. 2010. "Conventionalised Impoliteness Formulae." Journal of Pragmatics 42(12): 3232-3245. doi:10.1016/j.pragma.2010.05.007

Culpeper, Jonathan. 2011. Impoliteness: Using Language to Cause Offence. Cambridge: Cambridge University Press.

Delgado, Richard. 1982. "Words that Wound: A Tort Action for Racial Insults, Epithets, and Name-Calling." Harvard Civil Rights-Civil Liberties Law Review 17: 133-181.

Fraser, Bruce and William Nolen. 1981."The Association of Deference with Linguistic Form." International Journal of the Sociology of Language 27: 93-109. doi: $10.1515 /$ ijsl.1981.27.93 
This is the author accepted manuscript to appear in the Journal of Language, Aggression and Conflict. As such, it is under copyright; the publisher should be contacted for permission to re-use or reprint its material in any form.

Gabriel, Yiannis. 1998. "An Introduction to the Social Psychology of Insults in Organizations." Human Relations 51 (11): 1329-1354. doi:10.1023/A:1016946332565

Garcés-Conejos Blitvich, Pilar, and Maria Sifianou. Forthcoming. "(Im)politeness and Identity." In Handbook of Linguistic (Im)politeness, edited by Jonathan Culpeper, Michael Haugh and Dániel Kádár. Basingstoke: Palgrave.

Garcés-Conejos Blitvich, Pilar, Nuria Lorenzo-Dus, and Patricia Bou-Franch. 2013. "Identity and Impoliteness: The Expert in the Talent Show Idol." Journal of Politeness Research 9(1): 97-120. doi: 10.1515/pr-2013-0005

Garcés-Conejos Blitvich, Pilar. 2009. "Impoliteness and Identity in the American News Media: The Culture Wars." Journal of Politeness Research 5: 273-304. doi: 10.1515/JPLR.2009.014

Garcés-Conejos Blitvich, Pilar. 2013. "Face, Identity, and Im/politeness: Looking Backwards, Moving forward - From Goffman to Practice Theory." Journal of Politeness Research 9(1): 1-33. doi: 10.1515/pr-2013-0001

Goffman, Erving. 1967. Interactional Ritual: Essays on Face-to-face Behavior. Garden City, New York: Anchor Books.

Grice, H. Paul. 1975."Logic and Conversation." In Syntax and Semantics 3: Speech Acts, edited by Peter Cole and Jerry Morgan, 41-58. London and New York: Academic Press.

Harris, Sandra. 1984. "Questions as a Mode of Control in Magistrates' Courts." International Journal of the Sociology of Language 49: 5-28. doi: 10.1515/ijs1.1984.49.5

Holtgraves, Thomas. 2005."Social Psychology, Cognitive Psychology, and Linguistic Politeness." Journal of Politeness Research: Language, Behaviour, Culture 1: 73-93. doi: 10.1515/jplr.2005.1.1.73

Iganski, Paul. 2008. Hate Crime and the City. Bristol: The Policy Press.

Kleinke, Sonja, and Birte Bös. 2015. "Intergroup Rudeness and the Metapragmatics of Its Negotiation in Online Discussion Fora." Pragmatics 25(1): 47-71. doi: $10.1075 /$ prag. $25.1 .03 \mathrm{kle}$

Kurzon, Dennis. 1998. "The Speech Act Status of Incitement: Perlocutionary Acts Revisited." Journal of Pragmatics 29(5): 571-596. doi:10.1016/S0378-2166(97)00083-0

Lachenicht, Lance G. 1980."Aggravating Language: A Study of Abusive and Insulting Language." International Journal of Human Communication 13 (4): 607-688. doi: $10.1080 / 08351818009370513$

Langton, Rae. 1993. "Speech acts and unspeakable acts." Philosophy and Public Affairs 22: 293330.

Limberg, Holger. 2009. "Impoliteness and Threat Responses." Journal of Pragmatics 41(7): 13761394. doi:10.1016/j.pragma.2009.02.003

Locher, Miriam A. 2006. "Polite Behaviour within Relational Work: The Discursive Approach to Politeness." Multilingua 25 (3): 249-267. doi: 10.1515/MULTI.2006.015

Locher, Miriam A., and Derek Bousfield. 2008. "Introduction: Impoliteness and Power in Language." In Impoliteness in Language: Studies on its Interplay with Power in Theory and Practice, edited by Derek Bousfield, and Miriam A. Locher, 1-13. Berlin and New York: Mouton de Gruyter.

Locher, Miriam A., and Richard J. Watts. 2008. "Relational Work and Impoliteness: Negotiating Norms of Linguistic Behaviour." In Impoliteness in Language: Studies on its Interplay with Power in Theory and Practice, edited by Derek Bousfield, and Miriam A. Locher, 77-99. Berlin and New York: Mouton de Gruyter. 
This is the author accepted manuscript to appear in the Journal of Language, Aggression and Conflict. As such, it is under copyright; the publisher should be contacted for permission to re-use or reprint its material in any form.

Locher, Miriam. 2008. "Relational Work, Politeness and Identity Construction." In Handbooks of Applied Linguistics. Issue 2: Interpersonal Communication edited by Gerd Antos, and Eijos Ventola, 509-540. Berlin/New York: Mouton de Gruyter.

Martínez-Cabeza, Miguel A. 2009. "Dangerous Words: Threats, Perlocutions and Strategic Actions." In Cognitive Approaches to Language and Linguistic Data, edited by Wiesław Oleksy, and Piotr Stalmaszczyk, 269-284. Frankfurt: Peter Lang.

Matsuda, Mari. 1989. "Public responses to racist speech: considering the victim's story." Michigan Law Review 87: 2320-2381.

Millwood-Hargrave, Andrea. 2000. Delete Expletives?: Research Undertaken jointly by the Advertising Standards Authority, British Broadcasting Corporation, Broadcasting Standards Commission and the Independent Television Commission. London: ASA, BBC, BSC and ITC.

Rudanko, Juhani. 2006. "Aggravated Impoliteness and Two Types of Speaker Intention in an Episode in Shakespeare's Timon of Athens." Journal of Pragmatics 38(6): 829-841. doi:10.1016/j.pragma.2005.11.006

Spencer-Oatey, Helen D. M. 2007. "Theories of Identity and the Analysis of Face."Journal of Pragmatics 39: 639-656. doi:10.1016/j.pragma.2006.12.004

Spencer-Oatey, Helen D. M. 2008.Culturally Speaking: Managing Rapport through Talk across Cultures $\left(2^{\text {nd }} \mathrm{edn}\right)$. London and New York: Continuum.

Tedeschi, James T., and Richard B. Felson. 1994.Violence, Aggression, and Coercive Actions. Washington DC: American Psychological Association.

Terkourafi, Marina. 2001. Politeness in Cypriot Greek: A Frame-based Approach. Unpublished $\mathrm{PhD}$ dissertation. Cambridge: University of Cambridge.

Terkourafi, Marina. 2002. "Politeness and Formulaicity: Evidence from Cypriot Greek." Journal of Greek Linguistics 3: 179-201. doi: 10.1075/jgl.3.08ter

Terkourafi, Marina. 2003. "Generalised and Particularised Implicatures of Politeness." In Perspectives on Dialogue in the New Millennium, edited by Peter Kühnlein, Hannes Rieser, and Henk Zeevat, 151-166. Amsterdam: John Benjamins.

Thomas, Jenny. 1995. Meaning in Interaction: An Introduction to Pragmatics. London: Longman. Tracy, Karen. 2008. "'Reasonable Hostility': Situation-appropriate Face-attack."Journal of Politeness Research: Language, Behaviour, Culture 4 (2): 169-191. doi: 10.1515/JPLR.2008.009

Walters, Mark Austin. 2013. "Conceptualizing 'Hostility' for Hate Crime Law: Minding 'the Minutiae' when Interpreting Section 28(1)(a) of the Crime and Disorder Act 1998." Oxford Journal of Legal Studies 34(1): 47-74. doi: 10.1093/ojls/gqt021

Watts, Richard J. 2003. Politeness. Cambridge: Cambridge University Press.

Young, Stacy L. 2004. Factors that Influence Recipients' Appraisals of Hurtful Communication. Journal of Social and Personal Relationships 21: 291-303. doi: $10.1177 / 0265407504042833$

\footnotetext{
${ }^{1}$ The other type of face devised by Spencer-Oatey (2008) is relational face. However there are some difficulties in separating this type from social identity face, and it also proved to be the least relevant type of face (Culpeper et al. 2010).

${ }^{2}$ The Crown Prosecution Service (CPS) maintains a central record of prosecution outcomes, including cases flagged as hate crime, through its electronic Case Management System (CMS) and which are extracted through the related Management Information System (MIS) database. CPS
} 
data are available through its Case Management System (CMS) and associated Management Information System (MIS). The CPS collects data to assist in the effective management of its prosecution functions. The CPS does not collect data that constitutes official statistics as defined in the Statistics and Registration Service Act 2007. These data have been drawn from the CPS' administrative IT system, which (as with any large scale recording system) is subject to possible errors with data entry and processing. The figures are provisional and subject to change as more information is recorded by the CPS. The CPS is committed to improving the quality of their data and from mid-June 2015 introduced a new data assurance regime which may explain some unexpected variance in some future data sets. The official statistics relating to crime and policing are maintained by the Home Office (HO) and the official statistics relating to sentencing, criminal court proceedings, offenders brought to justice, the courts and the judiciary are maintained by the Ministry of Justice (MOJ).

${ }^{3}$ According to the Urban Dictionary, 'sand money' means "crazy insane money, like an Arab Sheik".

${ }^{4}$ This example flouts Grice's (1975) maxim of quality -- there is no evidence that the addressees are dead. This triggers a search for an implied meaning, a strong possibility being that the speaker is threatening that they will be dead. 